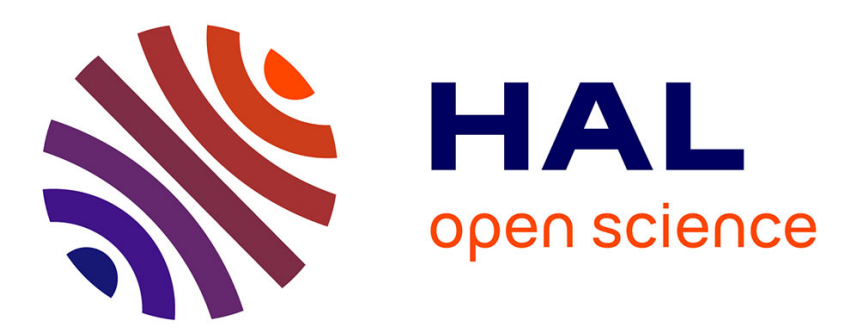

\title{
Conversing as Metaphor of Human Thinking: Is Mind like a Conversation?
}

Christine Sorsana, Alain Trognon

\section{To cite this version:}

Christine Sorsana, Alain Trognon. Conversing as Metaphor of Human Thinking: Is Mind like a Conversation?. Integrative Psychological and Behavioral Science, 2018, 52 (2), pp.241-256. 10.1007/s12124-018-9424-z . hal-03194769

\section{HAL Id: hal-03194769 \\ https://hal.science/hal-03194769}

Submitted on 9 Apr 2021

HAL is a multi-disciplinary open access archive for the deposit and dissemination of scientific research documents, whether they are published or not. The documents may come from teaching and research institutions in France or abroad, or from public or private research centers.
L'archive ouverte pluridisciplinaire HAL, est destinée au dépôt et à la diffusion de documents scientifiques de niveau recherche, publiés ou non, émanant des établissements d'enseignement et de recherche français ou étrangers, des laboratoires publics ou privés. 
REFERENCE TO BE USED FOR ANY QUOTATION OF THIS WORK:

Sorsana, C. \& Trognon, A. (2018). Conversing as metaphor of human thinking: Is mind like a conversation? Integrative Psychological and Behavioral Science, 52(2), 241-256.

https://doi.org/10.1007/s12124-018-9424-z

\section{RUNNING HEAD: IS MIND LIKE A CONVERSATION?}

\section{CONVERSING AS METAPHOR OF HUMAN THINKING:}

IS MIND LIKE A CONVERSATION?

Christine Sorsana, Universities of Toulouse Jean Jaurès and Lorraine (Nancy), France christine.sorsana@univ-tlse2.fr

Alain Trognon, University of Lorraine, Nancy, France

Alain.Trognon@univ-lorraine.fr

e-mail address, and telephone number(s) of the corresponding author:

Christine Sorsana, University of Toulouse Jean Jaurès, Department of Psychology

5 Allées Antonio Machado F-31058 Toulouse cedex 9

Phone number: +33 561504733

christine.sorsana@univ-tlse2.fr 
Is mind like a conversation? 
Is mind like a conversation?

\begin{abstract}
How can researchers shape their ideas so that they understand the mind better? This theoretical paper discusses the merits of the conversation metaphor as a means of analyzing the human mind. We will develop arguments concerning conversation as i) a situated and distributed activity, ii) a "product" in perpetual construction, and iii) the amount of credence and belief we afford it. Finally, we will advocate for metaphorical tools that promote a more dynamic conceptualization of human thinking.
\end{abstract}

Keywords: thinking development, conversation, mind, learning, pragmatics 
"Metaphor is not just a matter of language, that is, of mere words. On the contrary, human thought processes are largely metaphorical” (Lakoff and Johnson 1980, p. 6).

\section{Introduction}

Lakoff and Johnson $(1980,1999)$ emphasized that in order to think or speak about complex phenomena - for instance, our mental life -, we have no choice other than to conceptualize it using metaphors. In other words, we can understand something unattainable by using a simpler object. These conceptual metaphors are many and various, but none of them afford us a single, comprehensive and consistent understanding of our mind. Moreover, the objectivity thus described often refers to a dichotomized subject-object reality, whereas there are no objects-with-descriptions-and-categorizations existing in themselves, just as no (inter)subjectivity is disconnected from the world:

\footnotetext{
"Our understanding of what mental acts are is fashioned metaphorically in terms of physical acts like moving, seeing, manipulating objects, and eating, as well as other kinds of activities like adding, speaking or writing, and making objects. We cannot comprehend or reason about the mind without such metaphors. We simply have no rich, purely literal understanding of mind in itself that allows us to do all our important reasoning about mental life. Yet such metaphors hide what is perhaps the most central property of mind, its embodied character.

What we call 'mind' is really embodied. There is no true separation of mind and body. These are not two independent entities that somehow come together and couple. The word mental picks out those bodily capacities and performances that constitute our awareness and determine our creative and constructive responses to the situations we encounter. Mind isn't some mysterious abstract entity that we bring to bear on our experience. Rather, mind is part of the very structure and fabric of our interactions with our world" (Lakoff and Johnson 1999, p. 266).
}

If the embodiment of our thinking is related to the structure and construction of our interactions with our world, we suggest that it is probably better understood using the metaphor of conversation. Why? In line with such assumptions, we consider that the main 
metaphors about mind (mind is like a mental toolbox, mind is like a computer ...) are not convincing. If we want to use fruitful metaphors, we must find more dynamic metaphorical tools, which allow us to describe emerging processes. Thus, we suggest to take into account what human mind gives from itself: human mind represents itself as a mental activity within dialogue. That is, human beings invented an object simpler than mind in order to expose their mind, consciously or unconsciously: conversation. It is both a means to communicate and, a means to represent what is the functioning of human thinking. We will discuss the merits of the conversation metaphor as a means of analyzing the human mind.

\section{Conversation is a situated and distributed activity}

Let us look at how a conversation is gradually structured. The elementary structure of the conversational activity (speech act, nonverbal behavior such as a gesture or facial expression, etc.) contains at least three semiotic events. These are produced successively (at T1, T2 and T3) and distributed between at least two interacting partners A and B (Trognon 2002; Trognon and Batt 2010; Trognon and Brassac 1992; Trognon and Bromberg 2007; Trognon and Sorsana 2005). This elementary structure of the conversational activity can be schematized as follows (see Fig. 1):

$<$ Insert Figure 1 about here $>$

The following conversational examples, taken from Trognon and Brassac (1992, p. 97), allow us to complement Figure 1. 
(A window is opened)

1A: "There is a draught"

2B shuts the window

3A: "Thank you"

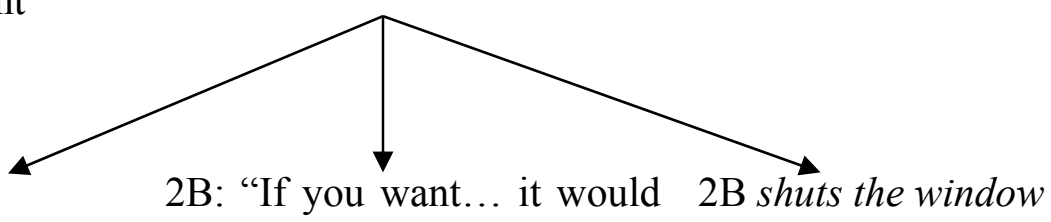

be kind of you"

3A shuts the window

4B: "Thank you"

5A: "You are welcome"
3A: "Hey I didn't ask you to shut it... But it was kind of you"

When Speaker A utters a statement with a particular intention at T1 (e.g., "There is a draught"), this statement is functionally unspecified: it is literally an assertion describing a reality (where a draught is present). But what meaning does s/he want to convey? At T2, Speaker B ventures to make an interpretation that is then enacted in the form of a speech act or a behavior. In other words, (T1A, T2B) constitutes an interpretive relationship that becomes mutually manifest and public for both interlocutors, as well as any observer. The third speech turn (T3) is key, as it allows the interactive partners to verify whether they have understood each other: A's reaction either ratifies B's interpretation of A's intention, as illustrated in the first column, or it contradicts it, as illustrated in the third column. In other words, [(T1A, T2B), T3A] constitutes an evaluative relationship, which is also both manifest and public. As we have already stressed elsewhere (Trognon and Sorsana 2005), the sequential order of conversation takes on the function of supporting and guiding the intersubjectivity, and at the same time constitutes a procedural solution to the problem of the interlocutors' mutual comprehension, even if this mutual comprehension is only rounded down (Trognon and Brassac 1992), that is, assumed until proved otherwise. Thus, the statements' function is determined retroactively and rounded down, regarded as the product of 
joint development that is constantly negotiable (Clark, 1996; Heritage 1990; Schegloff 1991; Trognon 2002; Trognon and Batt 2010). In consequence, when we engage in conversation, the product of our conversation is built step by step and in a distributed way between the interlocutors.

The same seems to be true of human thinking. There is a growing body of research in neurobiology, cognitive psychology and, of course, the social psychology of cognitive development, which describes human thinking as a situated and distributed activity. First, in neurobiology, the analogy between the brain and a computer has now been rejected, as the brain is increasingly characterized using conversational attributes:

\footnotetext{
"If the peripheral system is relatively refractory to the subject's experiences, the central nervous system is eminently malleable, prompt to answer the lessons of the past, by changing its form to modify its functions. Moreover, it is this faculty that renders the analogy between the brain and a computer completely inadequate. With one hundred thousand million processors and a quadrillion connections, the brain has no data processing equivalent. Concerning processors and software, an all too common error consists in wanting to apply the computer metaphor wholesale to the brain" (Vincent and Lledo 2012, p. 75).
}

So, in this field of research, thinking can be likened to a series of situated, distributed and multimodal actions that are organized in both contingent and co-operative ways by the neural network and all our sensory systems. In line with this view, when talking about the visual system, Varela and colleagues (1991) emphasized that the brain looks much more like a conversation in a café than a chain of orders.

Second, in psychology, a linguistic pragmatic turning point (Bernicot and Trognon 2002) concerned the whole of research, and prompted researchers to examine their comprehension of cognition, development, social transactions, language, pathology, and so on, from a new 
stance (Bernicot et al. 2002). In cognitive psychology, reasoning was inserted into pragmatic considerations (Hilton 1995; Politzer 1991, 1993, 2002, 2004; Politzer and Macchi 2000; Rossi and Van der Henst, 2008, Van der Henst 2002a). Considering language from a pragmatic point of view means considering all the elements carried by language from the point of view of their use (e.g., reasoning). Thus, today, even the cognitive approach has to take account of two facts that have been observed in concrete situations (Perret-Clermont et al. 1992; Trognon 1992, 1993; Trognon and Retornaz 1989):

“a) the subject's cognitive operations imply interaction with other subjects; and b) this interaction generally mobilizes language. This means we should try to tackle some concepts in a more rigorous-and empirically grounded-way" (Caron 1997, p. 233). These concepts include inference, representation, and language.

Some researchers have attempted to take up this key challenge in cognitive psychology, all the while expressing the following concerns: "If the study of reasoning begins with an analysis of the premises-in-context interpretation, then we must re-examine all the paradigms in the light of the pragmatics of language" (Politzer 1993, pp. 26-27; see Van der Henst $2002 \mathrm{~b}$ ); and, we will add, into the prototypical area of using language, that is to say, the dialogue. Doing it, researchers on cognitive psychology today consider that the cognitive subject is not a monad anymore. On the contrary, s/he permanently interacts with his/her environment, and in particular with his/her social environment, using language - in dialogue to accomplishing joint activities (Caron 1997, Jacques 1982, Trognon et al. 2003, 2006; Vernant 2011).

Finally, since many years, research in the field of the social psychology of cognitive development has accumulated empirical evidence about human thinking as a situated and distributed activity (Greenfield 2011; Hutchins 1995; Lave and Wenger 1991; Light and 
Butterworth 1992; Morelli and al. 2003; Rodríguez and Moro 2008; Rogoff 1990; Rogoff and Angelillo 2002; Saxe 1988, 2002; Schliemann and al. 1997; Sinha and Rodríguez, 2008; Valsiner 2009). The production of judgments, justifications, and inferences is largely influenced by conversational processes, and it is important to identify the conversational features that promote or hinder the cognitive progress (Light 1986; Light et al. 1987; Light and Perret-Clermont 1989; McGarrigle and Donaldson 1975; Perret-Clermont et al. 1992; Siegal 1991). It is through the communicative function that the human mind is realized synthetically, dynamically, and simultaneously in its emotional, social, and cognitive dimensions: "two or more persons in interaction constitute 'a thinking and acting system' whose mental characteristics 'are immanent not in some part, but in the system as a whole'" (Bateson 1973, p. 287).

\section{Conversation is not a given product but it is in perpetual construction}

When we engage in conversation, the product of our conversation is not foreseeable. Even if one of us initially has a precise communicative intention (e.g., an idea to be defended, an item of information to be given) various illocutory and interlocutory processes ${ }^{1}$ are possible and are jointly built as the exchanges with the interlocutor(s) unfold, because the speech-together produces something new. Thus, the fundamental and creative instability of conversational objects is dependent upon many components, starting with the collective development not only of the conversational content but also of the modalities of a) its unfolding and flow, b) and the production of its order and coherence, and ending in the development of the social bond itself (Berthoud and Mondada 1991). In other words, the meaning that is produced

\footnotetext{
${ }^{1}$ According to the philosopher Austin (1962), the smallest linguistic unit carrying a meaning (order, request, assertion, promise, etc.) that is intended to modify the situation of the interlocutors is called a speech act. In actual fact, when we produce a speech act, we simultaneously perform three acts: a locutory act (i.e., the production of a sequence of sounds that are syntactically organized and refer to something), an illocutory act (i.e., the accomplishment of an action that modifies the relationships between interlocutors: asserting, promising, etc.), and a perlocutory act (i.e., the consequence of what we have said for our interlocutor) (Maingueneau 1996).
} 
belongs neither to the speaker nor to the addressee; it is the emergent product of their relationship (Jacques 1982). This is possible because conversation is based on phenomenal constraints, that is, locality, overdetermination, and processuality (Trognon 1999, 2003). Locality refers to the fact that conversation is a locally organized and chaotic event (kind of nebula) from which thinking and social relationships emerge "less as the accomplishment of a preliminary plan than as the partially unintentional and gradual composition of a succession of actions, which are local and situated as defined by Suchman (1987)" (Trognon 1999, p. 72). Here, we find the idea of contingency, a feature of the interaction formats used by young children and adults to communicate (Bruner 1983, 1984). The concept of overdetermination means that every conversational element is at the same time a social event, a cognitive event, and an emotional event; it is as a social event that the social event contributes to the cognitive event, and vice versa, as well as it is as an emotional event that the emotional event contributes to the cognitive event, and vice versa. Finally, the concept of processuality "refers to the idea that the microscopic or macroscopic elements of a conversational sequence are gradually elaborated during the unfolding of the sequence (Trognon 1999, p. 74).

In addition, conversation, be it internal discourse (e.g., children's egocentric language, but also that of adults, when they are confronted with complex problems and are caught talking aloud) or social discourse, is, at the very least, the vehicle of our thinking. We can therefore assume that our thinking is richer than its linguistic expression. Moreover, like the conversational product, our thinking is not set in stone, but remains in perpetual construction; it is not a state but a process (English-speaking researchers should give up the thought word!). The development of thinking, like conversation, concerns both its content and the modalities of a) its unfolding, b) its ordering, and c) its coherence. Through a feedback mechanism, people can react to their thinking through the medium of their (public or private) statements. The organization of thinking, like conversation, is both synchronic and diachronic. 
So, we again find similarities with human thinking. One the one hand, with regard to brain plasticity, Vincent and Lledo (2012) specified that it does not seem to follow a preestablished program, and has much in common with do-it-yourself activity: "All these discoveries therefore show that cortical functions are closer to those of a multi-use pocket knife than to those of a brand new computer straight from IBM" (Vincent and Lledo 2012, p. 129). Moreover, thinking is a holistic activity, but has to be expressed sequentially, via language. This idea is neatly summed up by Donald (2001, p. 252): "Symbolic thought and language are inherently network phenomena. [...]. [T]he origin of language [lies] in cognitive communities, in the interconnected and distributed activity of many brains." On the other hand, as a result of research on cognition, it seems preferable to talk about how thinking is accomplished, rather than how it is planned or justified. Following the example of ethnomethodologists, we can relate the term accomplishment to a) the idea of the processual and local character of mental activity organization, b) unforeseeable circumstances that have to be processed, c) the limitations of planning, and d) the need to improvise in a given situation (Quéré 2006).

In brief, by analogy with contemporary physics, we can paraphrase Prigogine (1996) by stating that both conversation and thinking are unstable and creative dynamic systems, and knowing their initial conditions does not necessarily allow us to foresee their future (i.e., the conversational as well as cognitive products or, at the very least, their dual cognitive and social components ${ }^{2}$ ), or even talk about their past (i.e., speakers' genuine initial intentions).

\footnotetext{
${ }^{2}$ At least five components (affective, relational (e.g., affinity), cognitive, and social) are simultaneously realized within the conversational as well as the cognitive products, to which we can add the materiality of the objects that are manipulated.
} 
Is mind like a conversation?

\section{Conversation is based not on the truth of a situation, but on the amount of credence and belief we afford it}

When we engage in conversation, the product of our conversation is not based on the truth of what is being discussed. Rather, it is the amount of credence given to the representations contained in the partners' illocutions that determines whether the conversing continues. Manes Gallo and Vernant (1997, p. 17) called it a fiduciary pact (pacte fiduciaire in French; Vernant, 2011), that is to say, a pact based on trust. This is why conversation can be conceived of as a prototype for managing the intercomprehension of cognitions and the coconstruction of representations (Trognon 1997, 1999). As a consequence, taking into account the various levels of meaning involved in the conversational interplay "may allow us to closely describe, through the accomplishment of the illocutory acts, how the management of the relational characteristics may or may not support the development of negotiations over what is represented by the propositional content" (Gilly et al. 1999, p. 25) and, as a corollary, how some of the beliefs that are co-constructed during the flow of conversation can stabilize and turn into new knowledge (Baker 2009; Ghiglione and Trognon 1993; Searle 1969; Searle and Vanderveken 1985; Trognon 2002; Trognon and Batt 2010; Vanderveken 1990).

Like a conversation, thinking is based not on the truth of a situation, but on the amount of credence and belief we afford it (Engel 1994, 2004). It is thus not surprising that some developmental psychologists assume that it is children's increasing experience, not as agents but as conversationalists, that plays a determining role in their ability to understand the role of thoughts and beliefs, as the structure of conversation can draw their attention to a set of human abilities of which they had hitherto been unaware (Harris 1996, 1999, 2000; see also Deleau et al. 1999; Dunn et al. 1991; Veneziano 1998, 1999a). As has been well documented by Wertsch (1979/2008), children can develop self-regulation abilities while interacting within everyday communicative settings that involve the regulation of others. In short, the 
conversational activity supports and guides a) intersubjectivity, and constitutes b) the construction-in-action of mutual comprehension, as well as c) an interactional space favorable to learning (Sorsana 2003, 2005, 2011; Trognon et al. 2003, 2006; Trognon and Sorsana 2005; Veneziano 1998, 1999a, 1999b, 1999c).

In consequence, it is no longer possible to ignore the fact that children's (or adults') answers when confronted with, say, a problem to solve, a school assessment or a personality test are determined mainly by conversational interpretations of the questions being asked by the interviewer. In other words, the nature of people's answers depends on the goals they assign to illocutions. Every evaluation inevitably relates to a) knowledge about an object (of knowledge), b) the individual's ability to communicate about it, and c) the interlocutors' shared meanings of the lived situation (i.e., common ground, Clark 1992, 1996).

\section{Toward a program of formal analysis in the cognitive field of conversation}

Research questions have changed little since Piaget and Vygotsky conducted their groundbreaking work: what are the prerequisites of all knowledge, and how is the structure of intelligence or knowledge (as defined by Piaget) formed, the latter being conceived not as the acquisition and accumulation of information, but as its organization, regulated by systems of self-control directed toward adaptation (Piaget, 1992)? Adopting the more functionalist terminology used by Inhelder and colleagues (1992), we prefer to formulate this question as follows: how can we grasp the functional process that subtends the procedures used by children to solve sets of problems, by analyzing their step-by-step actions, mental blocks, procedural deadlocks, contradictions, and so on? 
The Piagetian clinical method is presented as a special technique for tracking the content of children's representations of the world, that is, the systems of intimate beliefs (or spontaneous beliefs - child's brainwave) they successively adopt across the various stages of intellectual development. This method of judging their beliefs has recently come in for criticism from pragmatic linguists. Because utterances are always a joint activity between at least two interlocutors (see Caron 1983; Ghiglione and Trognon 1993), it is impossible to strip the answers produced by a speaker (adult or child) of:

- "the influence of the asked question",

- "any logical character"

- "their verbal element" (Piaget 1926, pp. 25-26).

The successive transformations this method underwent, ultimately becoming a method of interactive observation (Inhelder et al., 1992) no longer fulfilled the aim of neutralizing (or controlling) the adult experimenter's interventions, even though Inhelder and her team made every effort to control these interventions "in a way that would not interfere with the child's mental processing of his/her knowledge" (Saada-Robert 1992, p. 141). Today, this goal is regarded as difficult to reach it.

In addition, observations of young children's pragmatic abilities (Garitte 1998; Harris 1996, 1999; Siegal and Surian 2007; Veneziano 1998, 1999a, 1999b, 1999c) contradict the assumption of children's linguistic coherence, assumed to be "of a type more organic than logical" and inadequately representing their thinking (Piaget 1926, p. 26). When spontaneous interactions are observed in the everyday-life situations, children as young as 3 years show themselves to be powerful partners in conversation with their peers and adults. The answers children give in experimental settings are no longer conceived as only symptoms or realities, 
but rather as the gradual composition of thinking-in-action from local and situated actions. This thinking-in-action process is, of course, embedded in a meeting between at least two individuals (a child and an experimenter). There are probably two reasons why children's pragmatic abilities were underestimated for so long. First, this particular area of linguistics went unrecognized until Morris (1955) gave it a name. It had previously been scorned even by linguists, who regarded pragmatics as the dustbin of linguistics. Second, experiment designs were based on conversational traps that went against certain general pragmatic principles (McGarrigle and Donaldson 1974; Donaldson 1978; Hargreaves et al. 1982; Light et al. 1987; Light and Perret-Clermont 1989; Miller 1982; Rose and Blank 1974; Samuel and Bryant 1984), possibly without the experimenters themselves realizing it.

The linguistic pragmatic turning point in psychology has had a triple impact on the field of studies about thinking (Bernicot and Trognon 2002). First, this pragmatic outlook reinforces the idea that cognition is not an abstract mental process but a situated one (Suchman 1987), that is, it depends on the actors' available resources as well as on the specific features of the situation in which this mental activity takes place. Similarly, it is not an individual but a distributed process, embodied in transactions related to human interactions connected to artifacts (Hutchins 1995). These transactions are not "the sum of the resources implemented by the partners. Rather, they are conceived of as joint and original constructions that emerge from a dynamic interaction. As Lave (1988) wrote, cognition arises from the dialectic relations between the actions of interacting people, the context of their activity, and the activity itself" (Bernicot \& Trognon 2002, p. 17; see Hutchins 1991, 1995; Sorsana and Trognon 2011; Trognon and Batt 2010; Trognon and Sorsana 2011; Trognon et al. 2008, 2011). Second, this pragmatic view leads to new conceptualizations of the nature of thinking: we can conceive that "cognition is neither phenomenally nor conceptually independent. At the very least, it is a mixture of communication and 'pure' cognition, whose relations largely remain to be defined" (Bernicot and Trognon 2002, p. 17; Trognon and Batt 2010; Trognon et al. 2011). Third and last, while most of our 
thinking emerges from interactions with others and within conversations, we still have to explain how it occurs within the conversational flow.

In line with this new context of investigation, the status of belief has also changed. Among the different conceptualizations suggested by developmental psychologists (Deleau 1999; Sorsana $2005)^{3}$, the intersubjective model advocated by Bruner $(1986,1990,1996)$ seems to give the best account of the fact that children experience being negotiators of beliefs very early on, in the unfolding of everyday spontaneous conversations, especially when a disagreement occurs. Because they have to simultaneously attend to conversational coherence and conduct, partners must produce statements that indicate their intentions, representations, and shifting interpretations and expectations (Teasley 1995). In short, communicative situations socially oblige speakers to make what they know, think and believe explicit, as well as to justify their own point of view and convince their interlocutors (Trognon and Batt 2013; Trognon et al 2011, 2011b). Analyzing the speech acts produced in conversations therefore allows us to ascertain the interlocutors' inner beliefs. In particular, “(...) an assertion engages the addressee, its purpose being to share a belief. The objective is to modify the addressee's doxastic state by providing him/her with a belief that $\mathrm{s} / \mathrm{he}$ is assumed not to share [...]. It should be stressed that it is a proposed answer to what is in question between the interlocutors" (Manès Gallo and Vernant 1997, p. 16; see also Brassac 1997). For these reasons, analyzing children's speech acts is instructive (see Bernicot (1992)'s work on the request speech act), and assertive speech acts are worth studying particularly thoroughly (Sorsana 2005). Such studies are, however, very few and far between, owing to the difficulty of operationalizing them (Bernicot and Bert-Erboul 2009).

\footnotetext{
${ }^{3}$ Two constructivist-type models link the ability to allocate beliefs to the development of thinking, from a mechanism of the subject's internal coordination (see Perner [1991]'s general model, as well as Wellman [1990]'s local model). A modularist model (Baron-Cohen, 1998) connects the concept of belief with primitive mechanisms resulting from our phylogenetic heritage, which are associated with those required for data processing. Lastly, an intersubjective model (Bruner, 1990, 1996) links the concept of belief to the concept of cognitive process enculturation, within practices of communication (in particular linguistic practices) that provide interpretative tools and frameworks.
} 
Given the empirical properties of conversation set out in the above sections, it seems logical to study communicative situations featuring child participants and experimenters in a more holistic way, analyzing all the various levels of discourse discernible in the conversational flow. This would allow us understand how some of the beliefs that are explicitly coconstructed in the course of the conversation stabilize and become new knowledge, under conditions that have yet to be described and formalized. The sequential order of conversation means we can elaborate a protocol of analysis that does not require the stratagems described by Inhelder and her team (see Chapter V in Inhelder et al. 1992; see Veneziano's (1997) works on the children's first lexis).

The empirical properties (or constraints) of conversation can be studied using a combination of tools that are currently available. Trognon (2000) drew up a list of specifications for formalizing the conversational inscription of rationality such as it is studied at the University of Lorraine (Nancy 2). These are summarized in Table 1. A model of the emergence of thinking from conversation has been developed by Trognon and colleagues (2011; see also Trognon and Batt 2013). This model describes a continuum running from rhetoric to demonstrative speech, the underlying idea being that demonstration is the best argument in a debate.

$<$ Insert Table 1 about here $>$

\section{Conclusion}

Far from being a mere rhetorical exercise, searching for the most relevant conceptual metaphors for researchers to use as conceptual tools in their theories allows us to identify 
those phenomena that are selected (and those that are ignored) in the construction of the scientific reality. These conceptual metaphors inform the scientific topics we investigate (Lakoff and Johnson 1980, 1999; Zittoun et al. 2007). Zittoun and colleagues (2007) undertook a critical analysis of the triangle metaphor, which is considered to be the most frequently used conceptual metaphor in developmental but also social and cultural psychology. This metaphor can be used to articulate the relationship between a subject, another person and the world, between three people, or between a person, ideas and concrete objects. The advantage of triangular rather than binary models is that they emphasize the fact that something or somebody mediates the relationship between a subject/agent and the world/object or its understanding (Zittoun et al. 2007). The authors singled out the triangles used to model the social basis of human cognition ${ }^{4}$, and more particularly those that illustrate different conceptualizations of the relationship between social interactions and cognitive development. Finally, these authors recommended relinquishing the triangle in favor of a structure with four vertices: the tetrahedron, in order to relate the main four components in theories of human development, i.e. person, other, object and, sign. However, we suggest, at least, two critical arguments against their proposals. First, we consider that this geometric metaphor gives the illusion of sociocognitive mediation in human thinking that is wellorganized in three poles, and can be predicted; these geometric metaphors (triangle, tetrahedron...) fix (or congeal) our representation of mind. On the contrary, human thinking seems to be dynamically constructed in a do-it-yourself, unforeseeable and opportunistic way. In other words, we have to choice or invent new metaphorical tools that grasp the emergent and embodied phenomenon of human thinking, and the dynamics of thinking cannot be wellapproached by a static geometric metaphorical tool. Second, when these authors introduced a fourth pole in order to overcome the limitation of the three-term-models, we consider that this

\footnotetext{
${ }^{4}$ Their analyses focused on the emotional (Freud and psychoanalysis), mediational (Vygotsky and sociocultural psychology) and sociocognitive triangles, based on Piagetian research.
} 
fourth pole - the sign - is the picture of all the three previous terms, and it is the only pole representing the three others, that is, for us, conversation. Human beings exploit dialogue in order to represent their psychological functioning, consciously or unconsciously. For that reason, conversing is both the means to communicate and, the means to expose what is thinking: contradiction, hesitation, breach of coherence ... in short, all the psychological human system exposes itself within conversation, even if, of course, conversation is only (or partially) gestural. It is as if human beings had invented conversation, simpler than mind, in order to expose their own mind (Mercier and Sperber, 2011; Trognon and Batt 2013). Thus, we can suggest that conversation is a natural metaphor, invented by mankind. In other words, if conversation is a fruitful metaphor it is because conversation is a symbol that mankind gives to itself and, which allows it $1 /$ to act, and $2 /$ to express its representation of itself, others, the world and all their relations.

Is mind like a conversation? In an ontological way, mind is different from conversation. However, human mind exposes itself within conversation. Conversation is the mirror of the mind that mankind gives to itself in order to cooperate. So, we believe the characteristics of conversation promote a more dynamic conceptualization of human thinking. Concepts such as internalization, interiorization, equilibration, appropriation, sociocognitive conflict, mentalization and symbolization would gain from being re-analyzed from this new interpretative perspective, which allows for fortuitous meetings and connections. 


\section{Acknowledgement}

We would like to thank Elizabeth Wiles Portier for comments on the English style.

\section{Compliance with Ethical Standards:}

This study was not funded.

Conflict of Interest: Author A declares that she has no conflict of interest. Author B declares that he has no conflict of interest.

Ethical approval: All procedures performed in studies involving human participants were in accordance with the ethical standards of the institutional and/or national research committee and with the 1964 Helsinki declaration and its later amendments or comparable ethical standards.

\section{References}

Austin, J. L. (1962). How to do things with words. Oxford: Oxford University Press.

Baker, M. (2009). Argumentative interactions and the social construction of knowledge. In N. Muller Mirza \& A.-N. Perret-Clermont (Eds.), Argumentation and education. Theoretical foundations and practices (pp. 127-144). Dordrecht, Heidelberg, London \& New York: Springer.

Baron-Cohen, S. (1998). Mindblindness: An essay on autism and theory of mind. Cambridge, MA: MIT Press. (original work published 1995)

Bateson, G. (1973) Steps to an ecology of mind: Collected essays in anthropology, psychiatry, evolution and epistemology. London: Paladin Books.

Bernicot, J. (1992). Les actes de langage chez l'enfant. Paris: Presses Universitaires de France.

Bernicot, J., \& Bert-Erboul, A. (2009). L'acquisition du langage par l'enfant. Paris: In Press Editions.

Bernicot, J., \& Trognon, A. (2002). Le tournant pragmatique en psychologie. In J. Bernicot, A. Trognon, M. Guidetti, \& M. Musiol (Eds), Pragmatique et psychologie (pp. 13-32). Nancy: Presses Universitaires de Nancy.

Bernicot, J., Trognon, A., Guidetti, M., \& Musiol, M. (Eds.) (2002). Pragmatique et psychologie. Nancy: Presses Universitaires de Nancy.

Berthoud, A. C., \& Mondada, L. (1991). Modes d'introduction et de négociation du topic dans l'interaction sociale. In D. Véronique \& R. Vion (Eds.), Modèles de l'interaction verbale (pp. 277-301). Aix-en-Provence: Publications de l'Université de Provence.

Brassac, C. (Ed.) (1997). L'assertion en débat. La description du monde dans la conversation. Psychologie de l'Interaction, 5-6. 
Bruner, J. S. (1983). Child's talk: Learning to use language. New York: W.W. Norton.

Bruner, J. S. (1984). Contextes et formats. In M. Deleau (Ed.), Langage et communication à l'âge préscolaire (pp. 13-26). Rennes : Presses Universitaires de Rennes.

Bruner, J. S. (1986). Actual minds, possible worlds. Cambridge, MA: Harvard University Press.

Bruner, J. S. (1990). Acts of meaning. Cambridge, MA: Harvard University Press.

Bruner, J. S. (1996). The culture of education. Cambridge, MA: Harvard University Press.

Caron, J. (1983). Les régulations du discours. Paris: Presses Universitaires de France.

Caron, J. (1997). Psychologie cognitive et interactions conversationnelles. In J. Bernicot, J. CaronPargue, \& A. Trognon (Eds.), Conversation, interaction et fonctionnement cognitif (pp. 221-237). Nancy: Presses Universitaires de Nancy.

Clark, H. H. (1992). Arenas of language use. Chicago, IL: University of Chicago Press.

Clark, H. H. (1996). Using language. New York: Cambridge University Press.

Deleau, M. (1999). Communiquer, imaginer, penser la pensée. In M. Deleau (Ed.), Psychologie du développement (pp. 190-241). Rosny: Bréal.

Deleau, M., Guehenneuc, K., Le Sourn, S., \& Ricard, M. (1999). Clairvoyance conversationnelle et théorie de l'esprit. Enfance, 3, 238-247.

Donald, M. W. (2001). A mind so rare. The evolution of human consciousness. New York, London: W.W. Norton \& Company.

Donaldson, M. (1978). Children's minds. London: Fontana.

Dunn, J., Brown, J., Slomkowski, C., Tesla, C., \& Youngblade, L. (1991). Young children's understanding of other people's feelings and beliefs: Individual differences and their antecedents. Child Development, 62, 1352-1366.

Engel, P. (1994). Introduction à la philosophie de l'esprit. Paris: La Découverte.

Engel, P. (2004). Belief. In O. Houdé, D. Kayser, O. Koening, J. Proust, \& F. Rastier (Eds.), Dictionary of Cognitive Science (pp. 125-127). New York and Hove : Psychology Press (original work published 1998)

Garitte, C. (1998). Le développement de la conversation chez l'enfant. Brussels: De Boeck Université.

Ghiglione, R., \& Trognon, A. (1993). Où va la pragmatique? De la pragmatique à la psychologie sociale. Grenoble: Presses Universitaires de Grenoble.

Gilly, M., Roux, J.-P., \& Trognon, A. (1999). Interactions sociales et changements cognitifs: Fondements pour une analyse séquentielle. In M. Gilly, J.-P. Roux, \& A. Trognon (Eds.), Apprendre dans l'interaction. Analyse des médiations sémiotiques (pp. 9-39). Aix-enProvence, Nancy: Presses de l'Université de Provence \& Presses Universitaires de Nancy.

Greenfield, P. (2011). Variabilité du développement humain: relier le changement social et le changement individuel. In B. Troadec \& T. Bellaj (Eds.), Psychologies et cultures (pp. 63119). Paris: L'Harmattan.

Hargreaves, D., Molloy, C., \& Pratt, A. (1982). Social factors in conservation. British Journal of Psychology, 73, 231-234.

Harris, P. L. (1996). Desires, beliefs and language. In P. Carruthers \& P. K. Smith (Eds.), Theories of theories of mind (pp. 200-220). Cambridge: Cambridge University Press. 
Harris, P. L. (1999). Acquiring the art of conversation: Children's developing conception of their conversation partner. In M. Bennet (Ed.), Developmental psychology: Achievements and prospects. London: Psychology Press.

Harris, P. L. (2000). The work of imagination. Oxford: Blackwell.

Heritage, J. C. (1990). Interactional accountability: A conversation analytic perspective. In B. Conein, M. De Fornel, \& L. Quéré (Eds.), Les formes de la conversation Volume 1. Paris: CNET.

Hilton, D. J. (1995). The social context of reasoning: Conversational inference and rational judgment. Psychological Bulletin, 118, (2), 248-271.

Hutchins, E. (1991). Organizing work by adaptation. Organization Science, 2(1), 14-39.

Hutchins, E. (1995). Cognition in the wild. Cambridge, MA: MIT Press.

Inhelder, B., Cellérier, G., Ackermann, E., Blanchet, A., Boder, A., De Caprona, D., Ducret, J.-J., \& Saada-Robert, M. (1992) (Eds.). Le cheminement des découvertes de l'enfant. Recherche sur les microgenèses cognitives. Neuchâtel: Delachaux \& Niestlé.

Jacques, F. (1982). Différence et subjectivité. Paris: Aubier.

Lakoff, G., \& Johnson, M. (1980). Metaphors we live by. Chicago, IL: University of Chicago Press.

Lakoff, G., \& Johnson, M. (1999). Philosophy in the flesh. The embodied mind and its challenge to Western thought. New York: Basic Books.

Lave, J. (1988). Cognition in practice. Mind, mathematics and culture in everyday life. Cambridge: Cambridge University Press.

Lave, J., \& Wenger, E. (1991). Situated learning: legitimate peripheral participation. New York: Cambridge University Press.

Light, P. (1986). Context, conservation and conversation. In M. Richards \& P. Light (Eds.), Children of social worlds: Development in social context (pp. 170-190). Cambridge: Polity Press.

Light, P., \& Butterworth, G. (1992) (Eds.). Context and cognition. New York: Harvester Wheatsheaf.

Light, P., Gorsuch, C., \& Newman, J. (1987). "Why do you ask?" Context and communication in the conservation task. European Journal of Psychology of Education, II (1), 73-82.

Light, P., \& Perret-Clermont, A.-N. (1989). Social context effects in learning and testing. In A. Gellatly, D. Rogers, \& J. A. Sloboda (Eds.), Cognition and social worlds (pp. 99-112). Oxford: Science Publications, University Press.

Maingueneau, D. (1996). Les termes clés de l'analyse du discours. Paris: Seuil (Mémo coll.).

Manes Gallo, M. C., \& Vernant, D. (1997). Pour une réévaluation pragmatique de l'assertion. Psychologie de l'Interaction, II (1 \& 2), 7-41.

McGarrigle, J., \& Donaldson, M. (1975). Conservation accidents. Cognition, 3(4), 341-350.

Mercier, H., \& Sperber, D. (2011). Why do humans reason? Arguments for an argumentative theory. Behavioral and Brain Sciences, 34, 57-111.

Miller, S. (1982). On the generalisability of conservation. British Journal of Psychology, 73, 221-230.

Morelli, G.A., Rogoff, B., \& Angelillo, C. (2003). Cultural variation in young children's access to work or involvement in specialised child-focused activities. International Journal of Behavioral Development, 27 (3), 264-274.

Morris, C. (1955). Signs language and behavior. New York: George Braziller. 
Perner, J. (1991). Understanding the representational mind. Cambridge, MA: MIT Press.

Perret-Clermont, A. N., Schubauer-Leoni, M. L., \& Trognon, A. (1992). L'extorsion des réponses en situation asymétrique. Verbum, 1-2, 3-32.

Piaget, J. (1926). La représentation du monde chez l'enfant. Paris: Presses Universitaires de France.

Piaget, J. (1992). Biologie et connaissance. Essai sur les relations entre les régulations organiques et les processus cognitifs. Paris, Neuchâtel: Delachaux \& Niestlé. (original work published 1967)

Politzer, G. (1991) (Ed.). Pragmatique et psychologie du raisonnement. Intellectica, 1(11).

Politzer, G. (1993). La psychologie du raisonnement: Lois de la pragmatique et logique formelle (Unpublished doctoral dissertation). University of Paris VIII, Paris.

Politzer, G. (Ed.) (2002). Le raisonnement humain. Paris: Hermès.

Politzer, G. (2004). Reasoning, judgment and pragmatics. In I. Noveck \& D. Sperber (Eds.), Experimental pragmatics (pp. 94-115). London: Palgrave.

Politzer, G., \& Macchi, L. (2000). Reasoning and pragmatics. Mind and Society, 1, 73-93.

Prigogine, I. (1996). La fin des certitudes. Paris: O. Jacob.

Quéré, L. (2006). Ethnométhodologie. Encyclopedia Universalis.

Rodríguez, C \& Moro, C. (2008). Coming to agreement. Object use by infants and adults. In J. Zlatev, T.P. Racine, C. Sinha, \& E. Itkonen (Eds.), The shared mind. Perspectives on intersubjectivity (pp. 89-114). Amsterdam \& Philadelphia: John Benjamins Company.

Rogoff, B. (1990). Apprenticeship in thinking: cognitive development in social context. New York \& Oxford: Oxford University Press.

Rogoff, B. \& Angelillo, C. (2002). Investigating the coordinated functioning of multifaceted cultural practices in human development. Human Development, 45, 211-225.

Rose, S., \& Blank, M. (1974). The potency of context in children's cognition. Child Development, 45, 499-502.

Rossi, S., \& Van der Hernst, J.-B. (Eds.) (2007). Psychologies du raisonnement. Brussels: Editions De Boeck Université.

Saada-Robert, M. (1992). Didier et les poupées russes: Analyse de cas et conceptualization. In IB. Inhelder, G. Cellérier, E. Ackermann, A. Blanchet, A. Boder, D. De Caprona, et al. (Eds.), Le cheminement des découvertes de l'enfant. Recherche sur les microgenèses cognitives (pp. 139-176). Neuchâtel: Delachaux \& Niestlé.

Samuel, J., \& Bryant, P. (1984). Asking only one question in the conservation experiment. Journal of Child Psychology and Psychiatry, 25, 315-318.

Saxe, G.B. (1988). The mathematics of child street vendors. Child Development, 59, 1415-1425.

Saxe, G.B. (2002). Children's developing mathematics in collective practices: A framework for analysis. The Journal of the Learning Sciences, 11 (2-3), 275-300.

Schegloff, E. A. (1991). Conversation analysis and socially shared cognition. In L. B. Resnick, J. M. Levine, \& S. D. Teasley (Eds.), Perspectives on socially shared cognition (pp. 150-170). Washington, DC: American Psychological Association. 
Schliemann, A.D., Carraher, D.W., \& Ceci, S.J. (1997). Everyday cognition. In J.W.Berry, P.R. Dasen \& T.S. Saraswathi (Eds.), Handbook of cross-cultural psychology, Vol. 2: Basic processes and human development (pp. 177-216). Boston: Allyn and Bacon.

Searle, J. (1969). Speech acts: An essay in the philosophy of language. Cambridge: Cambridge University Press.

Searle, J., \& Vanderveken, D. (1985). Foundations of illocutionary logic. Cambridge: Cambridge University Press.

Siegal, M., \& Surian, L. (2007). Conversational understanding in young children. In E. Hoff \& M. Shatz (Eds.), Handbook of language development (pp. 304-323). New York: Blackwell.

Siegal, M. (1991). A clash of conversational words: Interpreting cognitive development through communication. In L. B. Resnick, J. M. Levine, \& S. D. Teasley (Eds.), Perspectives on socially shared cognition (pp. 23-41). Washington, DC: American Psychological Association.

Sinha, C. \& Rodríguez, C. (2008). Language and the signifying object: From convention to imagination. In J. Zlatev, T.P. Racine, C. Sinha, \& E. Itkonen (Eds.), The shared mind. Perspectives on intersubjectivity (pp. 357-378). Amsterdam \& Philadelphia: John Benjamins Company.

Sorsana, C. (2003). Comment l'interaction coopérative rend-elle plus "savant"? Quelques réflexions à propos des conditions nécessaires au fonctionnement dialogique du conflit sociocognitif. L'Orientation Scolaire et Professionnelle, 32(3), 437-473.

Sorsana, C. (2005). Croyances et habiletés conversationnelles entre enfants: Réflexions à propos de la gestion dialogique des désaccords au sein des raisonnements. Psychologie de l'Interaction, 19-20, 39-97.

Sorsana, C. (2011). L'activité conversationnelle est-elle une fenêtre ouverte sur la pensée de soi et d'autrui? Enfance, 63(1), 69-91.

Sorsana, C., \& Trognon, A. (2011). Contextual determination of human thinking: About some conceptual and methodological obstacles in psychology studies. Human Development, 54(4), 204-233.

Suchman, L. (1987). Plans and situated actions. The problem of human-machine communication. Cambridge: Cambridge University Press.

Teasley, S. D. (1995). The role of talk in children's peer collaborations. Developmental Psychology, 31(2), 207-220.

Trognon, A. (1992). Psicologia cognitiva e analisi delle conversazioni. In C. Galimberti (Ed.), $L a$ conversazione: Prospettive sull'interazione psico-sociale (pp. pp. 115-157). Milan: Guerini Studio.

Trognon, A. (1993). How does the process of interaction work when two interlocutors try to resolve a logical problem? Cognition and Instruction, 11(3), 325-345.

Trognon, A. (1997). Conversation et raisonnement. In J. Bernicot, J. Caron-Pargue, \& A. Trognon (Eds.), Conversation, interaction et fonctionnement cognitif (pp. 253-282). Nancy: Presses Universitaires de Nancy.

Trognon, A. (1999). Eléments d'analyse interlocutoire. In M. Gilly, J. P. Roux, \& A. Trognon (Eds.), Apprendre dans l'interaction. Analyse des médiations sémiotiques (pp. 69-94). Aix-enProvence, Nancy: Presses de l'Université de Provence \& Presses Universitaires de Nancy. 
Trognon, A. (2000, July). Comment formaliser le domaine cognitif d'une conversation? Paper presented at the 7th International Pragmatics Conference (IPrA), Budapest.

Trognon, A. (2002). Speech acts and the logic of mutual understanding. In D. Vanderveken \& S. Kubo (Eds.), Essays in speech act theory (pp. 121-133). Amsterdam: John Benjamins and Sons.

Trognon, A. (2003). La productivité du malentendu. In M. Laforest (Ed.), Le malentendu: Dire, mésentendre, mésinterpréter (pp. 53-64). Quebec City: Nota Bene.

Trognon, A., \& Batt, M., (2010). Interlocutory logic: A unified framework for studying conversational interaction. In J. Streek (Ed.), New adventures in language and interaction (pp. 9-40). Brussels: John Benjamins Publishing Company.

Trognon, A., \& Batt, M. (2013). A new link in the Unification of the Sciences of Cognition (Commentary on Mercier: Using evolutionary thinking to cut across disciplines: the example of the argumentative theory of reasoning). In P. H. Crowley \& T. R. Zentall (Eds.), Comparative decision making (pp. 312-315). New York: Oxford University Press.

Trognon, A., Batt, M., Bromberg, M., Sorsana, C., \& Frigout, S. (2011). Les formes logiques de la parole en interaction (quelques bases de la logique interlocutoire). In P. Castel, E. SalesWuillemin, \& M. F. Lacassagne, (Eds.), Psychologie sociale, communication et langage. De la conception aux applications (pp. 327-348). Paris, Brussels: Editions De Boeck Université.

Trognon, A., Batt, M., \& Marchetti, E. (2011). Le dialogisme de la rationalité dans l'ordre de l'interaction. Bulletin de Psychologie, 64(5), 439-455.

Trognon, A., Batt, M., Schwarz, B.B., Perret-Clermont, A.N., \& Marro, P. (2003). L'apprentissage dans l'interaction. Essai de logique interlocutoire. In A. Herzig, B. Chaïb-Draa \& P. Math (Eds.), Modèles formels de l'interaction. Actes des secondes journées francophones de Lille (pp. 229-240). Toulouse : Cepaduès éditions.

Trognon, A., Batt, M., Schwarz, B.B., Perret-Clermont, A.N., \& Marro, P. (2006). Logique interlocutoire de la résolution en dyade d'un problème arithmétique. Psychologie Française, $51(2), 171-187$.

Trognon, A., Batt, M., \& Sorsana, C, \&. Saint Dizier de Almeida, V. (2011b). Argumentation and dialogue. In A. Trognon, M. Batt, J. Caelen, \& D. Vernant (Eds.), Logical properties of dialogue (pp. 147-186). Nancy: Presses Universitaires de Nancy.

Trognon, A., \& Brassac, C. (1992). L’enchaînement conversationnel. Cahiers de linguistique française, 13, 67-108.

Trognon, A., \& Bromberg, M. (2007). L'interaction sociale. In A. Trognon, \& M. Bromberg (Eds.), Psychologie sociale et ressources humaines (pp. 63-94). Paris: Presses Universitaires de France.

Trognon, A. \& Rétornaz, A. (1989). Clinique du rationnel: Psychologie cognitive et analyse des conversations. Connexions, 53, 69-91.

Trognon, A., \& Sorsana, C. (2005). Les compétences interactionnelles: Formes d'exercice, bases, effets et développement. Rééducation Orthophonique, 221, 29-56.

Trognon, A. \& Sorsana, C. (2011). Grasping both the normative facts and the social positions emerging from conversation. Human Development, Letters to the Editor, November 1, 11-17.

Trognon, A., Sorsana, C., Batt, M., \& Longin, D. (2008). Peer interaction and problem solving: One example of a logical-discursive analysis of a process of joint decision making. European Journal of Developmental Psychology, 5(5), 623-643. 
Valsiner, J. (2009). Contextualizing learning: How activity theories can change our conventional research practices in the study of development. Human Development, 52 (1), 69-76.

Van der Henst, J.-B. (2002a). La perspective pragmatique dans l'étude du raisonnement et de la rationalité. L'Année Psychologique, 102, 65-108.

Van der Hernst, J.-B. (2002b). Contexte et raisonnement. In G. Politzer (Ed.), Le raisonnement humain (pp. 272-305). Paris: Hermès.

Vanderveken, D. (1990). Meaning and speech acts. Cambridge: Cambridge University Press.

Varela, F., Thompson, E., \& Rosch, E. (1991). The embodied mind: Cognitive science and human experience. Cambridge, MA: MIT Press.

Veneziano, E. (1997). Echanges conversationnels et premières acquisitions langagières. In J. Bernico, J. Caron-Pargue, \& A. Trognon (Eds.), Conversation, interaction et fonctionnement cognitif (pp. 91-123). Nancy : Presses Universitaires de Nancy.

Veneziano, E. (1998). Buts illocutoires de l'assertion et enchâssement des forces: le cas de l'explication. Psychologie de l'Interaction, 5-6, 137-148.

Veneziano, E. (1999a). L'acquisition de connaissances pragmatiques: Apprendre à expliquer. Parole, 9-10, 1-27.

Veneziano, E. (1999b) (Ed.). La conversation: Instrument, objet et source de connaissance. Psychologie de l'Interaction, 7-8.

Veneziano, E. (1999c). La conversation: Instrument, objet et source de connaissance. Psychologie de l'Interaction, 7-8, 1-24.

Vernant, D. (2011). The dialogical logic of veridicity. In A. Trognon, M. Batt, J. Caelen, \& D. Vernant (Eds.), Logical properties of dialogue (pp. 123-145). Nancy: Presses Universitaires de Nancy.

Vincent, J.-D. \& Lledo, P.-M. (2012). Le cerveau sur mesure. Paris: O. Jacob.

Wellman, H. M. (1990). The child's theory of mind. Cambridge, MA: MIT Press.

Wertsch, J. V. (2008). From social interaction to higher psychological processes. A clarification and application of Vygotsky's theory. Human Development, 51, 66-79 (original work published 1979).

Zittoun, T., Gillespie, A., Cornish, F., \& Psaltis, C. (2007). The metaphor of the triangle in theories of human development. Human Development, 50, 208-229. 
Is mind like a conversation?

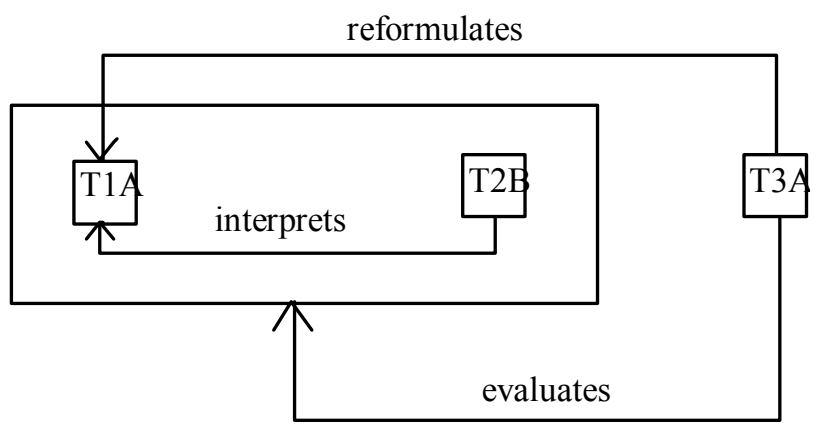

Figure 1. Elementary structure of conversational activity (from Trognon and Sorsana 2005, p. $33)$. 
Table 1.

Specifications for formalizing the cognitive domain of conversation (Trognon 2000)

\begin{tabular}{ll}
\hline Empirical properties (or constraints) & Theoretical tools satisfying these \\
of conversation & constraints
\end{tabular}

- Event-directed

- Irreversible (possibility of mutual understanding)

- Unforeseeable

- Gradually organized:

- by a succession of actions both social and cognitive, that are local, opportunistic (i.e., they are not planned) and distributed,

- producing thinking and social

relations,

- in the form of illocutions.
- Logic of natural deduction:

- reflects irreversibility;

- proceeds step by step.

- The speech act $F(p)$ simultaneously recreates the cognitive (p) and social $(\mathrm{F})$ dimensions.

- General semantics analyzes the semantics of the actions we perform through language.

- We have to complete this list with a logical model relating to the specific object of study.

Note. The theory of the hierarchical structure of conversation allows us to visualize the emergent architecture constituted by conversation. 